Urszula Soczyńska, Barbara Nowicka, Urszula Somorowska Stefan Ignar, Dariusz Górski, Jerzy Ostrowski

\title{
EVALUATION OF RAINFALL-RUNOFF MODELS PERFORMANCE FOR FLOOD COMPUTATION IN MOUNTAINOUS BASINS
}

\section{INTRODUCTION}

Investigations aimed to recognize possibility of rainfall flood simulation in ungauged basins are one of the important subjects in hydrological research. Many of such proposals can be found in literature. These proposals include simple conceptual rainfall-runoff models with only a few, easy to determine, parameters. This paper describes verification of: Wackermann model (two computational versions), Geomorphological Instantaneous Unit Hydrograph (GIUH) (three different versions) and Nash model with correlation formula developed by Lutz. The mentioned models refer to the theory of Instantaneous Unit Hydrograph and describe effective rainfall transformation into direct flow. Effective rainfall was evaluated with SCS (Soil Conservation Service) formula. The depth of effective rainfall is subject to the CN parameter depending on: soil type, land use, soil conservation practices and antecedent moisture conditions (Ignar, 1993). This parameter was determined for model verification by the comparison of recorded flood hydrograph with rainfall hyetograph which caused the flood. Investigated models were tested in two mountainous basins. Ten rainfall-runoff events were used for verification.

\section{STRUCTURE OF SELECTED MODELS}

The detailed description of selected models is given in the report "Prediction of rainfalls and floods with assumed time of recurrence" edited by Soczyńska (1995). 
Wackermann model

The Wackermann model of two parallel cascades consisting of two linear resorvoirs is very often used for rainfall-runoff transformation. The first cascade is interpreted as surface runoff transformation and the second cascade as subsurface flow transformation. Combined outflow from both cascades describes an IUH. The model has 3 parameters. They can be evaluated from empirical formulae referring to physiographical characteristics of the basin. There are two such characteristics applied; the horizontal projection of the channel length from the most distant point to the basin outlet and the slope between these two points. For the first computational version of the model (Wackermann I), model parameter values were evaluated from empirical formula developed by Thiele and Euler (1981). They were determined from data recorded in over 90 basins situated in the western part of Germany. Model parameter values for the second computational version (Wackermann II) were evaluated from formulae developed with the use of data recorded in 13 Polish basins (Ignar, 1993). Constant in time IUH is calculated for both computational versions for flood hydrograph simulation.

\section{GIUH models}

Three next models were developed as modifications of Geomorphological Instantaneous Unit Hydrograph described by Rodriguez-Iturbe and Valdes (1979). This is a physical interpretation of IUH as a density function of water drops time of concentration from all points of the basin to the basin outlet. IUH shape for this model depends on fixed basin parameters describing topological river network structure (parameters of Horton and Schumm laws) and on changed in time rainfall characteristics. Two versions of model includes also hydraulic parameters of river channel.

The Rodrigez-Iturbe and Valdes model with modification proposed by Rono (1989) was adopted for the first computational version (GIUH I). Two parameters of the gamma function decribing Nash cascade performance was used to describe the GIUH shape. Initial conditions of channel were also taken into account. A quasi-stationar form of the GIUH was assumed for this version, with GIUH evaluation for successive values of effective rainfall intensity. Another modification of the model was introduced for the second computational version (GIUH II). GIUH shape was additionally subject to rainfall duration (Nowicka, Soczyńska, 1991).

A shape of GIUH for the third computational version (GIUH III) was also described by two parameters of the gamma function. Model parameters 
were evaluated with the use of the empirical formula developed by Ostrowski (1994) from data recorded in 30 small basins investigated by IMGW and located in Poland. GIUH is subject to two time variant effective rainfall characteristics (rainfall duration and depth). As a result of this modification there are different unit hydrographs for each flood event.

\section{Nash-lutz model}

One of the four rainfall-runoff models used in the analysis was the Nash model along with empirical relationships given by Lutz (1984). Empirical relationships for IUH parameter estimation given by Lutz were based on the analysis of 961 flood events in 75 basins of the area up to $500 \mathrm{~km}^{2}$ from the territory of Germany. In the Nash model two IUH characteristics (concentration time and maximum ordinate) are necessary for identification of $\mathrm{N}$ and $\mathrm{K}$ parameters value. Relationships developed by Lutz allow an estimation of IUH characteristics on the basis of physico-geographical and precipitation characteristics. The concentration time is related to the following values:

- length of the river,

- distance from the river outlet to the point that is a projection of the basin gravity centre on the main river,

- average slope of the river channel,

- percentage of forested areas in total basin area,

- percentage of urbanized areas in total basin area,

- basin parameter dependent on roughness coefficient of river channel. The maximum ordinate of the IUH is estimated from concentration time and precipitation characteristics. Estimated in this way IUH characteristics are directly used for identification of IUH parameters $\mathrm{N}$ and $\mathrm{K}$.

The above method is attractive taking into account relatively simple procedure of parameters estimation related to physical characteristics as well as reach empirical data on which the method is based. The fact that the method was developed for climate conditions similar to Polish allows its application in this analysis. Further application of the method in relation to Polish conditions requires tests of models in greater number of basins.

\section{VERIFICATION OF MODELS}

\section{Characterization of basins chosen for analysis}

Verification of rainfall-runoff models has been conducted in two small mountainous basins of different physico-geographical characteristics. 
The Czarny River basin

The basin of Czarny at Polana cross-section has the area of $93.5 \mathrm{~km}^{2}$. It is situated in the north-east part of East Beskidy Mountains (South-West Carpathian Mountains). The geological base of the basin consits of glauconite sandstones and shales of Carpathian flysh. The presence of a relatively significant relief with regularly shaped mountain ranges and valleys of steep slopes have a great influence on hydrological situation. Differences in elevation are up to $400 \mathrm{~m}$.

A river network is well developed with the density of $3 \mathrm{~km} / \mathrm{km}^{2}$. It consists of two equivalent river systems of fifth order (Strahler's classification). These are the Czarny River System and Guuchy River System, coupling $100 \mathrm{~m}$ above Polana cross-section. The main river in the Czarny basin has a length of $17.23 \mathrm{~km}$ and a slope of 0.018 . The Hortons, and Schumms laws are fulfilled with the following values of their indexes: $R_{A}=4.16, R_{B}=3.57$, and $R_{L}=1.99$. Transitional forests (beech-fir forest) cover the basin in almost $70 \%$. Agricultural and waste lands occupy $29.1 \%$ of the total basin area, whereas residential area is $1.3 \%$. Mean annual precipitation is within the range of 800-900 mm (Atlas Hydrologiczny Polski, 1987). Total precipitation during summer season is much more higher than during winter time and is estimated at $550 \mathrm{~mm}$. The highest peak flows occur as a result of intensive rainfall events as well as snow melting. Surface runoff constitutes $55-70 \%$ of the total runoff. Annual specific outflow from the basin is estimated at 15 $\mathrm{l} / \mathrm{s} / \mathrm{km}^{2}$.

The Ślęża river basin

Ślęza river basin at Białobrzezie cross-section has an area of $177 \mathrm{~km}^{2}$. It is situated within two physico-geographical units: Sudety Foot-Hills and Silesian Lowland. South part of the basin situated within Sudety Foot-Hills is formed with quaternary deposits. Characteristic features are crystalic and metamorphic outcrops of older age. The northern part of the basin located within Sileasian Lowland has the less diversified cover. River channel is regulated with embankments.

Density of river network is $1.66 \mathrm{~km} / \mathrm{km}^{2}$ that is much lower than in the Czarny River basin. In this case Hortons and Schumms Laws are fulfilled with the following values of their indexes: $R_{A}=4.83, R_{B}=4.15$ and $R_{L}=2.39$. The slope of the main river channel is more than two times higher than in the case of Czarny river. The dominant type of land use is agriculture (76\% of total basin area). The percentage of the area covered with forests is $18 \%$ (spruce, pine-spruce, spruce-larch, oak-beech forests). The residential area occupies $5 \%$ of the total area.

The mean annual precipitation is $200 \mathrm{~mm}$ lower than in the Czarny River basin. Also in this case summer season precipitation is higher than 
during winter season. The contribution of surface runoff to the total runoff is lower than in the Czarny River basin and is within the range of $40-55 \%$. The annual specific outflow from the basin varies from $3-4 \mathrm{l} / \mathrm{s} / \mathrm{km}^{2}$.

\section{Description of analysed flood events}

Nine summer flood events from the Czarny River basin and Ślęża River basin were chosen for the verification of models. The analysed rainfallrunoff episodes are from the period 1977-1990. The chosen characteristics of flood events are presented in Table 1.

Table 1

Chosen characteristics of flood events

\begin{tabular}{|c|c|c|c|c|c|c|}
\hline $\begin{array}{c}\text { No. } \\
\text { of } \\
\text { event }\end{array}$ & $\begin{array}{l}\begin{array}{l}\text { Date of } \\
\text { event }\end{array}\end{array}$ & $\begin{array}{l}\text { Antecedent } \\
\text { Precipitation } \\
\text { (mm) }\end{array}$ & $\begin{array}{l}\text { Duration of } \\
\text { rainfall } \\
\text { (h) }\end{array}$ & $\begin{array}{l}\text { Duration of } \\
\text { runoff } \\
\text { (h) }\end{array}$ & $\begin{array}{c}\text { Maximum } \\
\text { observed } \\
\text { intensity } \\
\text { of rainfall } \\
(\mathrm{mm} / \mathrm{h})\end{array}$ & $\begin{array}{c}\text { Maximum } \\
\text { observed } \\
\text { intensity } \\
\text { of runoff } \\
\left(\mathrm{m}^{3} / \mathrm{s}\right)\end{array}$ \\
\hline \multicolumn{7}{|c|}{ a) The Czarny River basin at Polana } \\
\hline 1 & 11.06 .86 & 12.6 & 8 & 27 & 13.2 & 3.47 \\
\hline 2 & 30.05 .86 & 7.1 & 12 & 20 & 5.2 & 2.55 \\
\hline 3 & 24.05 .86 & 2.6 & 10 & 25 & 7.6 & 4.88 \\
\hline 4 & 08.06 .90 & 25.7 & 8 & 34 & 3.6 & 6.45 \\
\hline 5 & 08.08 .90 & 2.2 & 29 & 31 & 7.4 & 4.05 \\
\hline \multicolumn{7}{|c|}{ b) The Slęża River basin at Białobrzezie } \\
\hline 1 & 19.08 .77 & 8.8 & 26 & 46 & 3.6 & 8.24 \\
\hline 2 & 17.06 .79 & 27.0 & 31 & 71 & 17.0 & 21.0 \\
\hline 3 & 03.07 .80 & 19.2 & 25 & 51 & 6.7 & 15.9 \\
\hline 4 & 19.08 .77 & 8.8 & 41 & 96 & 5.9 & 19.3 \\
\hline
\end{tabular}

Antecedent precipitation accounted during 5-day period prior to the event in all analysed cases was within the range $2.2-27 \mathrm{~mm}$. The maximum observed rainfall intensity was $13.8 \mathrm{~mm} / \mathrm{h}$ in the Czarny River basin (flood event no. 1) and $17 \mathrm{~mm} / \mathrm{h}$ in the Slęża River basin. The analysed events were mostly caused by the rainfall of short duration in the case of the Czarny River basin (8-29 h) and longer duration in the case of the Sleqzia River basin (25-41 h). The duration of flood runoff was relatively short in the Czarny River basin (20 to 34 hours) and longer in the Slęża River basin (46 to 96 hours). The maximum observed runoff was within the range $2.55-6.45 \mathrm{~m}^{3} / \mathrm{s}$ in the Czarny River basin and $8.2-21 \mathrm{~m}^{3} / \mathrm{s}$ in the Sleezza River basin. The maximum observed runoff corresponds to the maximum probable runoff of high probabilities in the Czarny River basin (100\%) and low probabilities in the Ślęża River basin. 
The observed and simulated hydrograph plots were used for model verification (Fig. 1,2) together with three statistical characteristics (Table 2). The ratio of maximum calculated to observed flow $\left(Q_{\text {comp. }} / Q_{\text {obs. }}\right)$ was adopted as the first characteristic. Two others were: time lag at observed and computed flow peaks (p) and special correlation coefficient (Rs). Five grade classification was adopted for model evaluation. Rs values were taken after Delleur (1973).

The model quality investigation conducted in the Czarny River basin has shown usefulness of most of them for rainfall floods simulation (Fig. 1, Table 2a). GIUH III model has got the best results. For 5 tested hydrographs there were: 1 excellent result, 3 very good and 1 good. There were up two hours time lag at simulated hydrographs as compared with the observed ones. Peak flows were lower up to $67 \%$ of observed values.

Verification calculations for GIUH I model did not give satisfactionary results. There were 3 values of Rs lower then 0.85 . Discrepancies of peak flows were also significant. For the GIUH II model verification there have been obtained 3 very good and 1 good results. The flow peaks were usually lower and delayed in time.

The results for Wackermann models were satisfactionary, good and very good for one case. Peak flows were ahead of observed ones and most often lower then observed. Differences in maximum flows were in the range of $10-52 \%$ for I version of the model. The results for version II were better and peak flows differed by $8-33 \%$. The Nash model modified by Lutz gave very good results for three cases and not satisfactory for one case. There were not one-sided discrepancies.

Verification calculations conducted for the Slęża River basin have shown that in most cases simulated hydrographs were higher than the observed ones (Table 2b). It was usually in case of 2 and 4 events. The differences were in the range of $12-53 \%$ for 2 events and $60-125 \%$ for 4 events.

The best result were obtained for the simple Wackermann I (Fig. 1, Table 2b) model. There was 1 excellent result, 1 very good, 1 satisfactionary and 1 dissatisfactionary out of four events. The worst results in both basins were obtained for GIUH model. For other models results are not synonymous. The GIUH III model can be distinguished when comparing to other ones. 

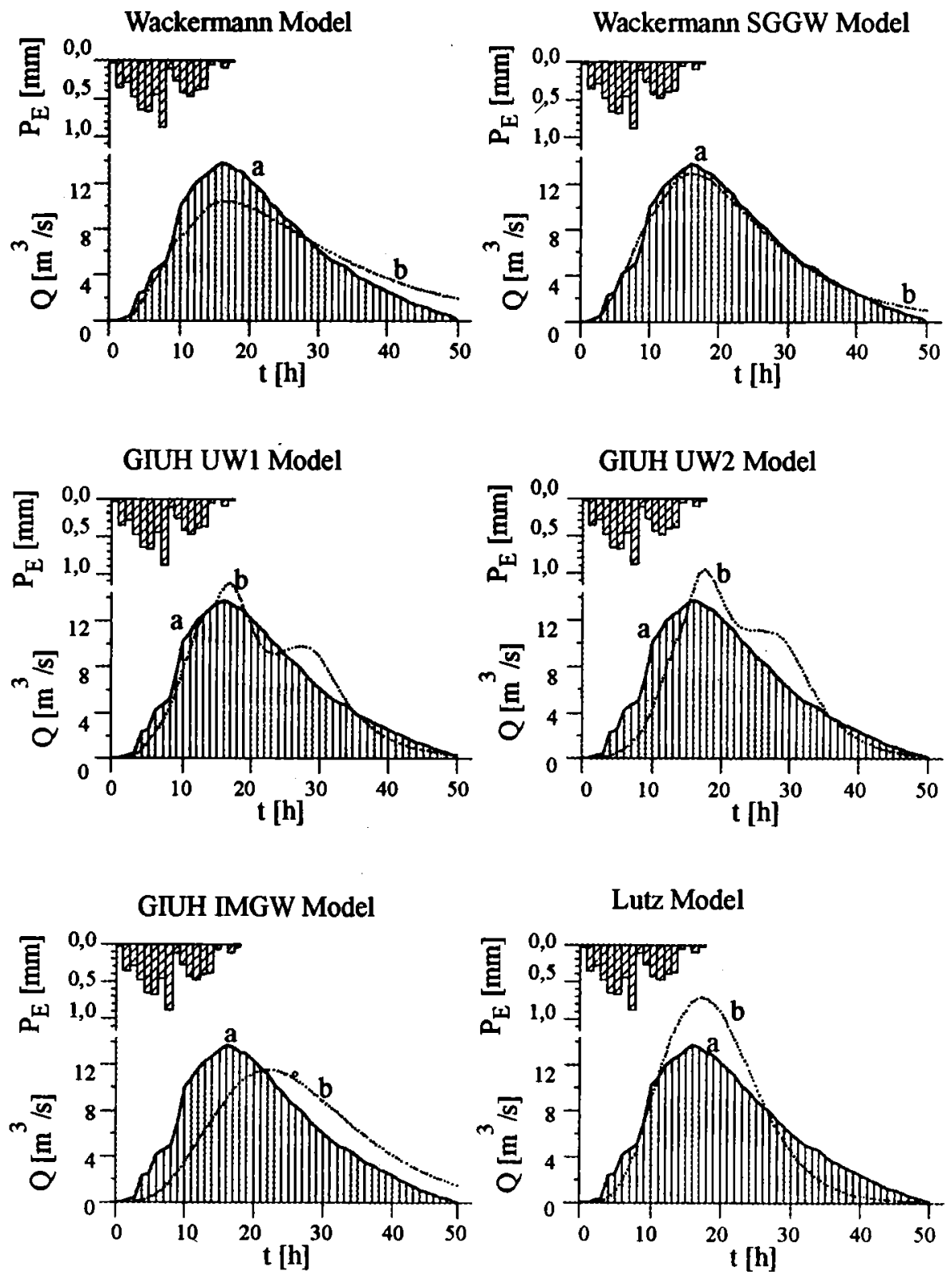

Fig. 1. Hydrograph simulation results in Slęża River basin at Białobrzezie cross-section, 07.08.1980 a - observed hydrograph, b - calculated hydrograph 

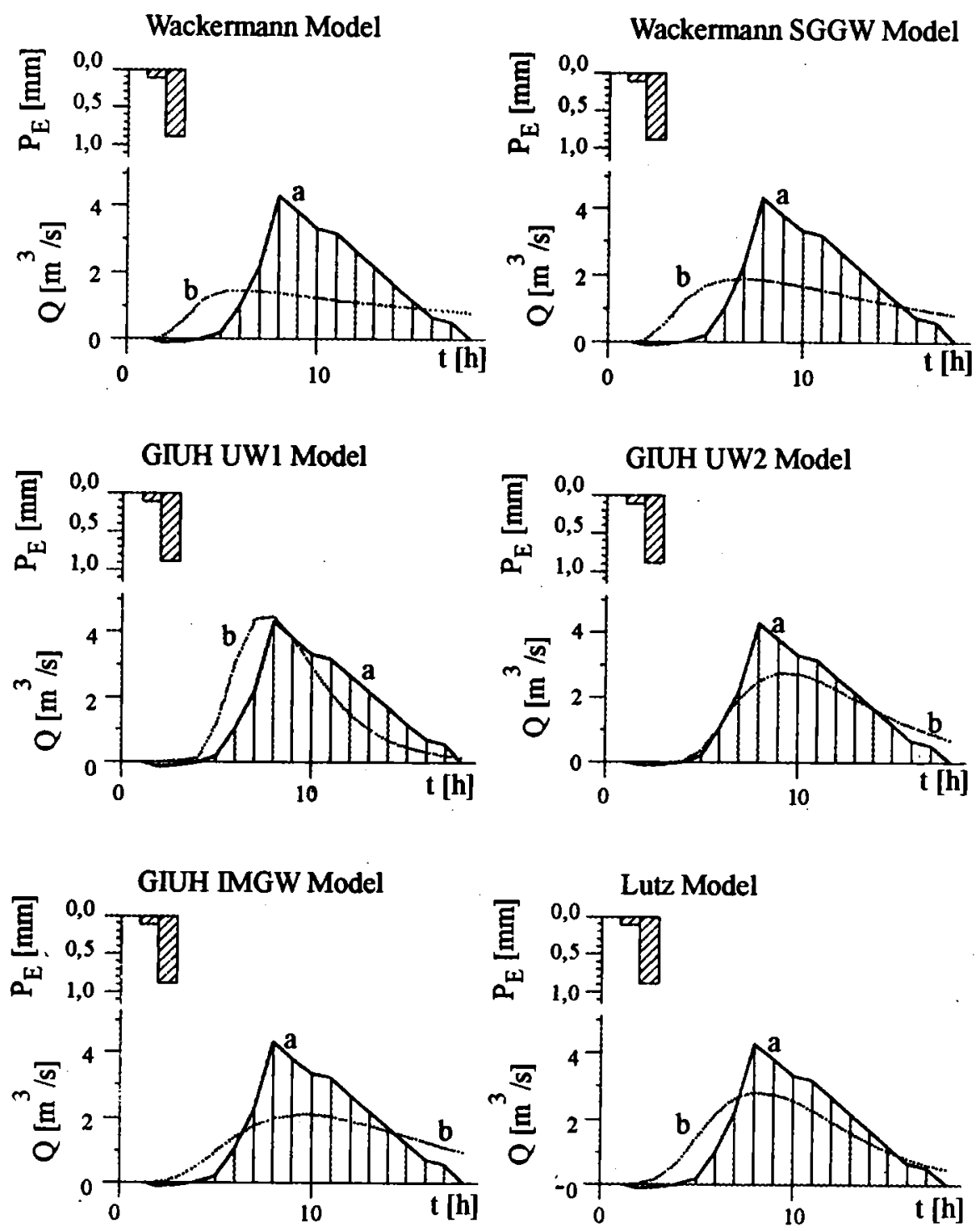

Fig. 2. Hydrograph simulation results in Czarny River basin at Polana cross-section, 07.03.1980 a - observed hydrograph, b - calculated hydrograph 
$\stackrel{\sim}{\stackrel{0}{a}}$

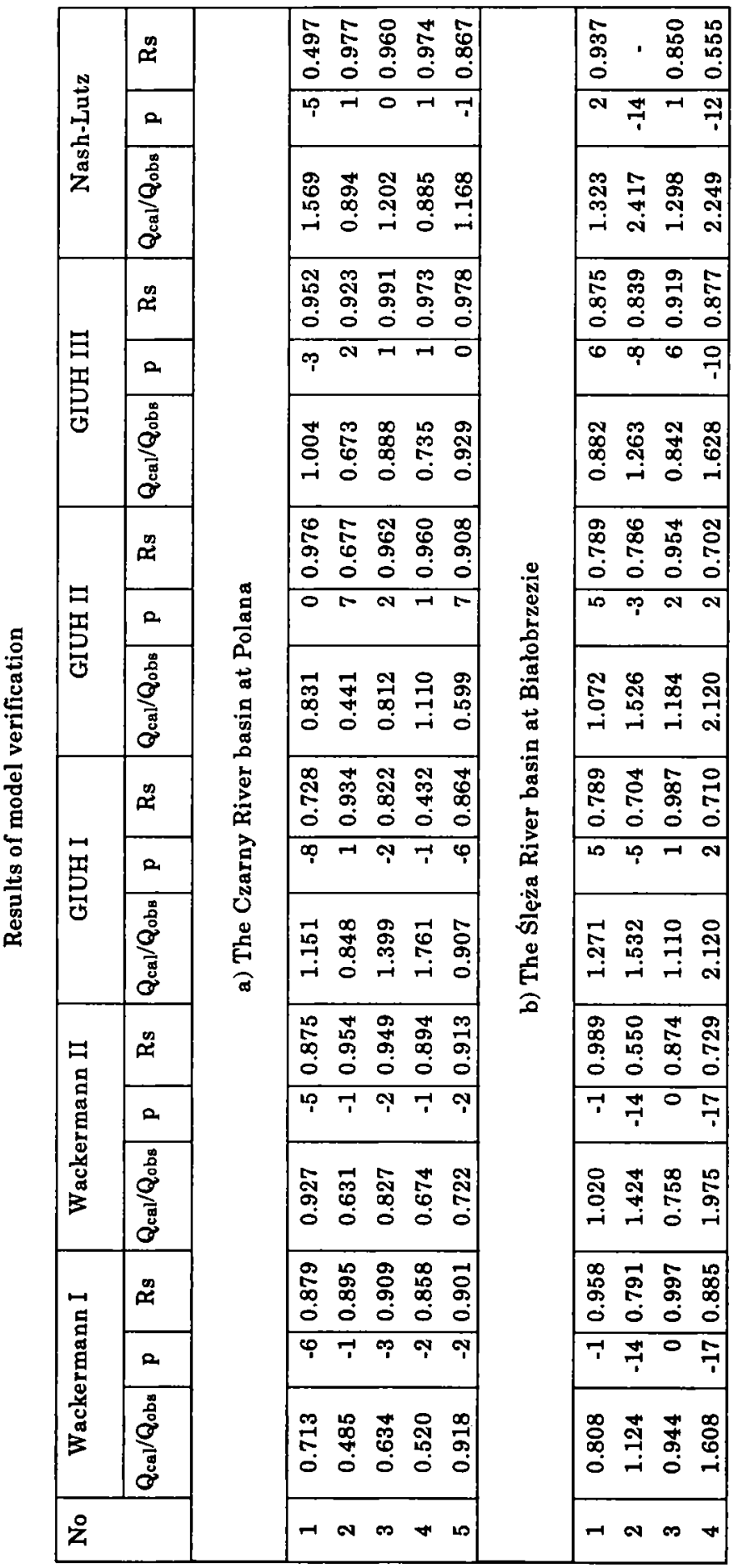


Atlas Hydrologiczny Polski 1986, IMGW, Wydawnictwa Geologiczne, Warszawa.

Dell e u r J.W., S a rma R.B.S., R a o A.R., 1973, Comparison of rainfall-runoff models for urban areas, $J$. of $H y d r$., vol. 18, no. 3-4.

I g n a r S., 1993, Metodyka obliczania przeptywów wezbraniowych w zlewniach nieobserowanych, Wydawnictwo SGGW.

Lutz W., 1984, Berechnung von Hoch wasser Ablüssen unter Anwendung von Gebietskenngrössen Mitteilungen, $I H W$, H. 24, Karsluhe.

Nowicka B., Soczyńska U., 1991, Modelowanie odpływu powierzchniowego metoda geomorfologiczna i hydrodynamiczna, Prac. i Stud. Geogr., t. 12.

Ostrow s ki I., 1994, Model regionalny matej zlewni "MOREMAZ-1", Mat. Badawcze, seria: Hydrologia i Oceanalogia, 17, IMGW Warszawa.

Predykcja opadów i wezbrán o zadanym czasie powtarzalności, 1995, ed. Soczyńska $\mathrm{U}$. , in print.

Rodrigez-It u rbe I., Valdas I.B., 1979, The geomorphologic structure of hydrologic response, Water Resources Res., vol. 15, no. 6. 